\title{
The role of magnetic resonance imaging and clinical assessments in predicting meniscal tear surgery
}

\author{
Menisküs yırtığı cerrahisini öngörmede manyetik rezonans görüntüleme \\ ve klinik değerlendirmenin rolü \\ Yaman Karakoç, MD (D), İsmail Burak Atalay, MD (D) \\ Department of Orthopedics and Traumatology, \\ Dr. Abdurrahman Yurtaslan Ankara Oncology Training and Research Hospital, Ankara, Turkey
}

\begin{abstract}
Objectives: This study aims to investigate the role of physical examination and magnetic resonance imaging (MRI) findings in predicting meniscal tear surgery.

Patients and methods: Medical records of a total of 997 patients (563 females, 434 males; mean age 40.53 years; range 18 to 66 years) who were recommended surgery for meniscal tear in an external center, but continued follow-up in our hospital between January 2012 and March 2018 were retrospectively analyzed. Data of the patients including demographic and clinical characteristics, physical examination findings, and MRI results were recorded. The visual analog scales (VAS) scores and the Knee Injury and Osteoarthritis Outcome Score (KOOS) were evaluated.
\end{abstract}

Results: Of all the patients evaluated by MRI, $62.4 \%$ were recommended surgical treatment in private hospitals and $37.6 \%$ were recommended surgical intervention in state hospitals. Only 282 of them (28.3\%) were treated surgically for meniscal tear after MRI evaluation and physical examination in our clinic. The median pre-treatment VAS score was 7.0 (range, 4 to 10 ) and 6.0 (range, 3 to 8 ) in the patients undergoing surgery and undergoing conservative treatment, respectively. The VAS and KOOS scores were similar between the groups at the postoperative sixth month and first year $(\mathrm{p}=0.940, \mathrm{p}=0.203 ; \mathrm{p}=116, \mathrm{p}=0.057$, respectively). Pain scores significantly decreased, while the KOOS scores significantly increased after the treatment in both groups (for all $\mathrm{p}=0.001$ ).

Conclusion: Decision for surgery should be solely based on physical examination and radiological findings in meniscal tears.

Keywords: Arthroscopy, clinical examination, magnetic resonance imaging, meniscal tear, nonsurgical treatment.

\section{ÖZ}

Amaç: Bu çalışmada menisküs yırtığı cerrahisini öngörmede fizik muayene ve manyetik rezonans görüntüleme (MRG) bulgularının rolü araştırıldı.

Hastalar ve yöntemler: Ocak 2012-Mart 2018 tarihleri arasında menisküs yırtığ 1 nedeniyle başka bir merkezde cerrahi önerilmiş, ancak takibine hastanemizde devam eden toplam 997 hastanın (563 kadın, 434 erkek; ort. yaş 40.53 yıl; dağılım, 18-66 yıl) tıbbi verileri retrospektif olarak incelendi. Demografik ve klinik özellikler, fizik muayene bulguları ve MRG sonuçları dahil olmak üzere hasta verileri kaydedildi. Görsel analog ölçeği (GAÖ) skorları ve Diz İncinme ve Osteoartrit Sonuç Skoru (KOOS) değerlendirildi.

Bulgular: Manyetik rezonans görüntüleme ile değerlendirilen tüm hastalardan \%62.4'üne özel hastanelerde cerrahi tedavi ve \%37.6'sına devlet hastanelerinde cerrahi girişim önerildi. Bu hastaların yalnızca 282'si (\%28.3) MRG değerlendirmesi ve fizik muayene sonrasında kliniğimizde menisküs yırtığ nedeniyle cerrahi olarak tedavi edildi. Tedavi öncesi medyan GAÖ skoru cerrahi yapılan grupta 7.0 (dağılım, 4-10) ve konservatif tedavi uygulanan grupta 6.0 (dağılım, 3-8) idi. Cerrahi sonrası altıncı ayda ve birinci yılda GAÖ ve KOOS skorları gruplar arasında benzerdi (sirasiyla $\mathrm{p}=0.940, \mathrm{p}=0.203$; $\mathrm{p}=116, \mathrm{p}=0.057)$. Her iki grupta da tedavi sonrası ağrı skorları anlamlı düzeyde azalırken, KOOS skorları anlamlı düzeyde arttı (tümü için p=0.001).

Sonuç: Menisküs yırtıklarında cerrahi kararı, fizik muayene ve radyolojik bulgular ile birlikte verilmelidir.

Anahtar sözcükler: Artroskopi, klinik değerlendirme, manyetik rezonans görüntüleme, menisküs yırtı̆̆ı, cerrahi dışı tedavi.

Received: February 13, 2019 Accepted: May 11, 2019 Published online: June 13, 2019

Correspondence: İsmail Burak Atalay, MD. Dr. Abdurrahman Yurtaslan Ankara Onkoloji Eğitim ve Araştırma Hastanesi Ortopedi ve Travmatoloji Kliniği, 06200 Demetevler, Ankara, Turkey. Tel: +90312336-0909 e-mail: drburakatalay@gmail.com 
Meniscal tears are one of the most common reasons for the adults to apply to a clinician for knee pain. About $35 \%$ of individuals over 50 years of age have a meniscal tear, and two-thirds of them are asymptomatic. ${ }^{[1]}$ There are studies about the clinical validity of magnetic resonance imaging (MRI), physical examination, and medical history in the diagnosis of meniscal tears. ${ }^{[2]}$ Clinical examination of the knee has been reported in the literature to reveal a meniscal tear with an accuracy ratio of 64 to $85 \%$. There are also studies that MRI is effective in defining meniscal, ligamentous, and tendinous injury and in predicting the degree of the chondral and

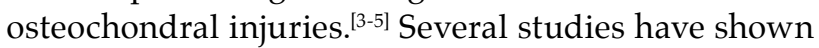
that MRI is the gold standard diagnostic tool in the noninvasive evaluation of the pathologies inside the knee. $^{[6-8]}$

The most common reason of arthroscopic knee surgeries is the meniscal tears. ${ }^{[7]}$ Partial excision or debridement (menisectomy) of the torn meniscus are the most common and known methods. There may be some risks after this type of operations, such as decrease in the meniscal functions in the knee, osteoarthritis, and cartilage destruction. Another method is the suturation of the tear. Although this method requires more experience and is more difficult, there is a possibility that the meniscus may heal. As acute tears happen mostly in sports injuries due to overloading, chronic tears are based on degeneration due to subtle traumas. On the other hand, healing potential is weak in degenerative tears due to inadequate blood supply. Though, conservative treatment programs implemented after tear in middleaged patients who are more prone to degenerative tears are found to be closely effective as partial menisectomy.

Surgical decision is not an easy one in pathologies regarding the inner joint. Complaints, anamnesis, physical examination findings, and MRI images must be evaluated together in making any treatment decision. Surgical treatment must be carried out to whom the symptoms are recurrent, despite conservative treatment. The superiority of the surgical treatment over conservative treatment has not been shown in selected patient groups. ${ }^{[9-12]}$

In the light of these data, a thorough physical examination has been thought to be the most effective in defining and choosing the treatment method of meniscal pathologies. In the present study, we aimed to investigate the role of physical examination and MRI findings in predicting meniscal tear surgery in patients referred from an external center.

\section{PATIENTS AND METHODS}

Medical records of a total of 997 patients (563 females, 434 males; mean age 40.53 years; range 18 to 66 years) who were recommended surgery for meniscal tear in an external center, but continued follow-up in our hospital between January 2012 and March 2018 were retrospectively analyzed. Those who had the initial diagnosis of meniscal tear with an evidence of MRI in an external center and recommended a surgical intervention were included. Those with incomplete medical records and pre- and post-treatment VAS scores were excluded from the study. A written informed consent was obtained from each patient. The study protocol was approved by the Dr. Abdurrahman Yurtaslan Ankara Oncology Training and Research Hospital Ethics Committee. The study was conducted in accordance with the principles of the Declaration of Helsinki.

\section{Arthroscopic surgery group}

Arthroscopic meniscus surgery was implemented to 282 patients $(28.3 \%)$ of all patients included. The operations were done under pneumatic tourniquet application, and mostly spinal and general anesthesia was preferred. Partial menisectomy or meniscal suturing was chosen according to the suitability of the repair. They were allowed to mobilize with crutches, but not allowed to load the operated side during one month postoperatively. The patients who were under close follow-up were allowed full weight-bearing after two months.

\section{Management of the non-operative group}

A total of 715 patients $(71.7 \%)$ were treated conservatively. The main goals of conservative treatment are to decrease pain and effusion, to keep muscle strength and joint proprioception, and to get patient back to normal walking pattern. Home-based physical therapy programs, resting, ice application, and non-steroidal anti-inflammatory drugs are the non-surgical treatment protocol in meniscal tears. Muscle relaxants and analgesics were also added to treatment for certain patients.

\section{Assessment tools}

The visual analog scale (VAS) was used to measure knee pain during the last week at rest and during daily activities and sports. No pain was graded 0 and maximal pain was graded 10 on a $100-\mathrm{mm}$ scale. The Knee Injury and Osteoarthritis Outcome Score (KOOS) is a specific scale used in evaluating knee functions and knee-related quality of life. It is composed of five subscales as pain, patient's perception for 
other symptoms, daily life, sports and recreational activities, and 42 items. ${ }^{[13]}$ Scoring ranges between 0 and 100. 0 indicates abnormally high level of knee problems, while 100 indicates a healthy knee with no problems. The reliability and validity studies of the Turkish version of the KOOS were carried out by Paker et al. ${ }^{[14]}$ Pain and KOOS scores were recorded in our clinic before the treatment and at six and 12 months after the treatment.

\section{Statistical analysis}

Statistical analysis was performed using the IBM SPSS version 22.0 software (IBM Corp., Armonk, NY, USA). Categorical variables were expressed in number and percentage, while continuous variables were expressed in mean \pm standard deviation (SD) and median (min-max) values. The relevance of continuous variables to normal distribution was evaluated using the visual (histogram and probability graphics) and analytical methods (Kolmogorov-Smirnov/ShapiroWilk tests). For categorical variables, whether there was a difference with respect to frequency between the groups was compared using the chi-square test. The Mann-Whitney U test was used for the comparison of abnormally distributed data between the groups. The Wilcoxon test was used to evaluate the change in pain score before and after treatment. A $p$ value of $<0.05$ was considered statistically significant.

\section{RESULTS}

Among all patients, 56.5\% of the MRI reports showed medial meniscal tear, $36.9 \%$ showed lateral meniscal tear, and $6.6 \%$ showed bilateral meniscal tear. Tear was located in the right knee in $49.7 \%$, in the left knee in $45.2 \%$, and bilateral in $5.1 \%$ (Table I). The distribution of the location of the meniscal tear according to the side was similar among the patients $(\mathrm{p}=0.824)$, (Figure 1).

Of the patients who were evaluated in an external center, $62.4 \%$ were recommended surgical treatment in private hospitals and $37.6 \%$ in state hospitals. Only 282 of them (28.3\%) were treated surgically for meniscal tear based on MRI evaluation and

TABLE I

Demographic and clinical characteristics of patients

\begin{tabular}{|c|c|c|c|c|c|}
\hline Parameters $(\mathrm{n}=997)$ & $\mathrm{n}$ & $\%$ & Mean \pm SD & Median & Min-Max \\
\hline Age (year) & & & $40.53 \pm 11.7$ & 40.0 & $18.0-66.0$ \\
\hline \multicolumn{6}{|l|}{ Gender } \\
\hline Female & 563 & 56.5 & & & \\
\hline Male & 434 & 43.5 & & & \\
\hline \multicolumn{6}{|l|}{ Side } \\
\hline Right knee & 495 & 49.6 & & & \\
\hline Left knee & 451 & 45.2 & & & \\
\hline Bilateral & 51 & 5.1 & & & \\
\hline \multicolumn{6}{|l|}{ Tear in magnetic resonance imaging } \\
\hline Medial & 563 & 56.5 & & & \\
\hline Lateral & 368 & 36.9 & & & \\
\hline Bilateral & 66 & 6.6 & & & \\
\hline \multicolumn{6}{|l|}{ The center of first application } \\
\hline State & 375 & 37.6 & & & \\
\hline Private & 622 & 62.4 & & & \\
\hline \multicolumn{6}{|l|}{ Treatment } \\
\hline Arthroscopic surgery & 282 & 28.3 & & & \\
\hline Conservative treatment & 715 & 71.7 & & & \\
\hline \multicolumn{6}{|l|}{ Arthroscopic surgery } \\
\hline \multicolumn{6}{|l|}{ Conservative treatment } \\
\hline $\begin{array}{l}\text { Concomitant disease of the patients } \\
\text { took conservative treatment }(n=715)\end{array}$ & 312 & 43.7 & & & \\
\hline Patellofemoral arthritis & 214 & 29.9 & & & \\
\hline Sinus tarsi syndrome & 189 & 26.4 & & & \\
\hline Sciatalgia & & & & & \\
\hline
\end{tabular}

SD: Standard deviation; Min: Minimum; Max: Maximum. 
TABLE II

Baseline demographic characteristics of patient groups

\begin{tabular}{|c|c|c|c|c|c|c|c|c|c|c|c|}
\hline & \multicolumn{5}{|c|}{ Surgical treatment } & \multicolumn{5}{|c|}{ Conservative treatment } & \multirow[b]{2}{*}{$p$} \\
\hline & $\mathrm{n}$ & $\%$ & Mean $\pm S D$ & Median & Min-Max & $\mathrm{n}$ & $\%$ & Mean $\pm S D$ & Median & Min-Max & \\
\hline Age (year) & & & $41.01 \pm 11.75$ & 40.0 & $18.0-66.0$ & & & $40,3 \pm 11,7$ & 40.0 & $18.0-65.0$ & $0.9661^{*}$ \\
\hline Gender & & & & & & & & & & & $0.6452^{\star *}$ \\
\hline Female & 156 & 55.3 & & & & 407 & 56.9 & & & & \\
\hline Male & 126 & 44.7 & & & & 308 & 43.1 & & & & \\
\hline
\end{tabular}

SD: Standard deviation; Min: Minimum; Max: Maximum; * Independent Sample t-test; ** Pearson chi-square test.

TABLE III

Pain scores before and after treatment

\begin{tabular}{|c|c|c|c|c|c|c|c|}
\hline & \multicolumn{3}{|c|}{ Surgical treatment } & \multicolumn{3}{|c|}{ Conservative treatment } & \multirow[b]{2}{*}{$p$} \\
\hline & Mean \pm SD & Median & Min-Max & Mean $\pm S D$ & Median & Min-Max & \\
\hline \multicolumn{8}{|c|}{ Surgical treatment group } \\
\hline Pain score & $6.8 \pm 1.2$ & 7.0 & $4.0-10.0$ & $1.2 \pm 1.2$ & 1.0 & $0-6.0$ & $0.001^{*}$ \\
\hline \multicolumn{8}{|c|}{ Conservative treatment group } \\
\hline Pain score & $5.5 \pm 1.2$ & 6.0 & $3.0-8.0$ & $1.21 \pm 1.1$ & 1.0 & $0-6.0$ & $0.001^{*}$ \\
\hline$p^{* *}$ & & 0.001 & & & 0.940 & & \\
\hline
\end{tabular}

SD: Standard deviation; Min: Minimum; Max: Maximum; * Wilcoxon test; *^ Mann-Whitney U test.

physical examination in our clinic (Table I). There was no significant difference in the age and sex of the patients undergoing surgery or conservative treatment (Table II). Among 375 patients who were recommended surgical treatment in an external center in state hospital, only $29.6 \%$ were treated surgically in our clinic, while of 622 patients who were recommended surgical treatment in a private hospital, only $27.5 \%$ were operated. The patients who were recommended surgical treatment in a state or private hospital were treated surgically at a similar rate in our clinic $(\mathrm{p}=0.474)$ (Figure 2$)$.

According to physical examination and imaging results of 715 patients, $43.6 \%$ had coexisting patellofemoral arthritis, $29.9 \%$ had coexisting sinus tarsi syndrome, and $26.4 \%$ had additional sciatalgia.
All these patients were given conservative treatment. While the patients with patellofemoral arthritis and sciatalgia were given medical treatment plus exercise, the patients with sinus tarsi syndrome were only given medical treatment.

Pre- and post-treatment pain scores are shown in Table 3. The median pre-treatment VAS score was 7.0 (range, 4 to 10) and 6.0 (range, 3 to 8 ) in the patients undergoing surgery and undergoing conservative treatment, respectively. The VAS scores were statistically significantly higher than the conservative group ( $\mathrm{p}=0.001)$. In addition, total KOOS scores before the treatment was significantly lower in the surgery group than the conservative group $(\mathrm{p}=0.001)$. The VAS and KOOS scores were similar between the groups at the postoperative sixth month and first year

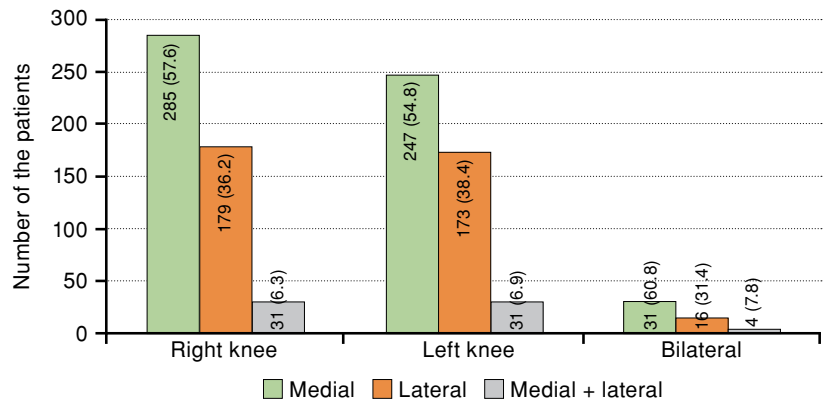

Figure 1. Distribution according to knee localization of meniscal tears on magnetic resonance imaging $(p=0.824)$.

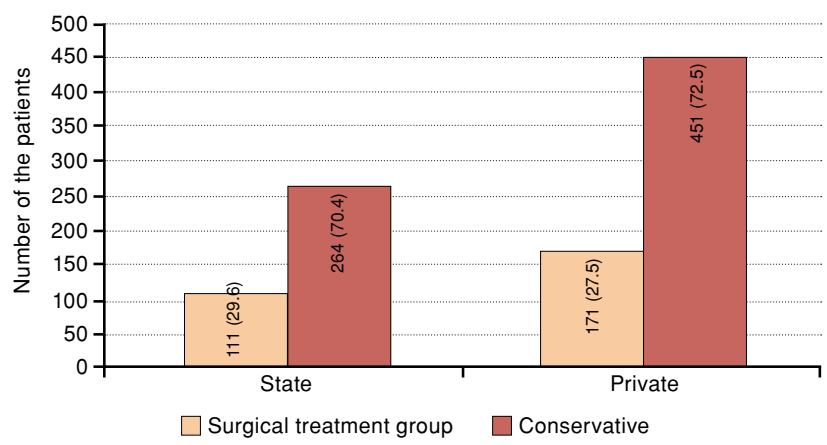

Figure 2. Distribution according to the initial center $(p=0.474)$. 
( $p=0.940, p=0.203 ; p=116, p=0.057$, respectively). Pain scores significantly decreased, while the KOOS scores significantly increased after the treatment in both groups (for all $\mathrm{p}=0.001$ ).

\section{DISCUSSION}

Meniscal tears are one of the leading causes of knee pain in orthopedic practice. Popping, clicking, and loosening may accompany to the pain. Furthermore, balance problems may be seen during walking. ${ }^{[15]}$ In the diagnosis of meniscal tears, MRI is used frequently. Although the sensitivity and specificity of MRI are high, it may show meniscal tears incidentally in $20 \%$ of cases without any knee symptoms. ${ }^{[1]}$ In several studies, false-positive MRI findings mimicking meniscal tears such as meniscal degeneration, scar formation, or meniscal calcification were considered as overlooked tears in arthroscopy. ${ }^{[16,17]}$

There are both conservative and surgical methods in the treatment of painful meniscal tears. To decide surgery based on solely MRI findings is inadequate. Esmaili et al. ${ }^{[18]}$ reported that physical examination had an accuracy of $96.9 \%$, while MRI had an accuracy of $85.9 \%$ in medial meniscal injuries and these ratio were $85.4 \%$ and $73.8 \%$, respectively for lateral meniscus injuries. The localization, the time elapsed, the type of tear, complaints, and physical examination findings must be considered in the decisionmaking process. Surgical treatment must be carried out to whom the symptoms are recurrent, despite conservative treatment. Conservative treatment must be given as the first-line treatment choice to the appropriate meniscal tears. On the other hand, patients having mechanical symptoms are more suitable for surgery. Ryzewicz et al. ${ }^{[19]}$ reported that a meticulous physical examination by an experienced clinician was as trustworthy as MRI in surgically treatable meniscal lesions.

In our study, the patients were younger in both treatment groups, compared to previous studies. ${ }^{[9-11,20,21]}$ The age and sex distributions of the groups receiving surgical or conservative treatment were similar. Even if the pain score of the patients who underwent surgery was higher compared to those who did not undergo surgery before treatment, pain scores after treatment were found not to be statistically different. Even if they had mechanical pains, the patients who were treated conservatively had as good results as those who were treated surgically. In several studies comparing the results of conservative treatment and arthroscopic treatment showed that the results of conservative treatment were as satisfactory as that of surgical treatment in the literature. ${ }^{[9-11,20]}$

In the present study, physical functions of the patients were evaluated by the KOOS scores before the treatment and also at six and 12 months after the treatment. The physical functions in the surgery group were worse than that the conservative group before the treatment. A significant improvement was observed after the treatment in both groups. In addition, physical functions at six and 12 months after the treatment were similar for both groups. In this study, both treatment choices yielded similar results in the long-term in terms of pain and physical functions. In a meta-analysis conducted by van de Graaf et al. ${ }^{[22]}$ including randomized-controlled studies comparing arthroscopic menisectomy and conservative treatment outcomes, surgical treatment was found to be superior to conservative treatment based on the KOOS scores. In this meta-analysis, there was no significant difference between the operation and conservative groups in terms of pain and physical functions according to the KOOS and scores at 12 and 24 months during follow-up. This finding is also consistent with the literature. ${ }^{[7,23,24]}$

In conclusion, our priority as orthopedic surgeons must be to treat the patient, not the imaging results. In meniscal tears, surgery decision should be merely based on both clinical examination and radiological findings together.

\section{Declaration of conflicting interests}

The authors declared no conflicts of interest with respect to the authorship and/or publication of this article.

\section{Funding}

The authors received no financial support for the research and/or authorship of this article.

\section{REFERENCES}

1. Englund M, Guermazi A, Gale D, Hunter DJ, Aliabadi $\mathrm{P}$, Clancy $\mathrm{M}$, et al. Incidental meniscal findings on knee MRI in middle-aged and elderly persons. N Engl J Med 2008;359:1108-15.

2. Meserve BB, Cleland JA, Boucher TR. A meta-analysis examining clinical test utilities for assessing meniscal injury. Clin Rehabil 2008;22:143-61.

3. Felli L, Garlaschi G, Muda A, Tagliafico A, Formica M, Zanirato A, et al. Comparison of clinical, MRI and arthroscopic assessments of chronic ACL injuries, meniscal tears and cartilage defects. Musculoskelet Surg 2016;100:231-8.

4. Kocabey Y, Tetik O, Isbell WM, Atay OA, Johnson DL. The value of clinical examination versus magnetic resonance imaging in the diagnosis of meniscal tears and anterior cruciate ligament rupture. Arthroscopy 2004;20:696-700. 
5. Majewski M, Susanne H, Klaus S. Epidemiology of athletic knee injuries: A 10-year study. Knee 2006;13:184-8.

6. Fischer SP, Fox JM, Del Pizzo W, Friedman MJ, Snyder SJ, Ferkel RD. Accuracy of diagnoses from magnetic resonance imaging of the knee. A multi-center analysis of one thousand and fourteen patients. J Bone Joint Surg [Am] 1991;73:2-10.

7. Miller GK. A prospective study comparing the accuracy of the clinical diagnosis of meniscus tear with magnetic resonance imaging and its effect on clinical outcome. Arthroscopy 1996;12:406-13.

8. Shakoor D, Kijowski R, Guermazi A, Fritz J, Roemer FW, Jalali-Farahani S, et al. Diagnosis of Knee Meniscal Injuries by Using Three-dimensional MRI: A Systematic Review and Meta-Analysis of Diagnostic Performance. Radiology 2019;290:435-45.

9. Herrlin S, Hållander M, Wange P, Weidenhielm L, Werner S. Arthroscopic or conservative treatment of degenerative medial meniscal tears: a prospective randomised trial. Knee Surg Sports Traumatol Arthrosc 2007;15:393-401.

10. Herrlin SV, Wange PO, Lapidus G, Hållander M, Werner $S$, Weidenhielm L. Is arthroscopic surgery beneficial in treating non-traumatic, degenerative medial meniscal tears? A five year follow-up. Knee Surg Sports Traumatol Arthrosc 2013;21:358-64.

11. Katz JN, Brophy RH, Chaisson CE, de Chaves L, Cole BJ, Dahm DL, et al. Surgery versus physical therapy for a meniscal tear and osteoarthritis. N Engl J Med 2013;368:1675-84.

12. Atik OŞ. Should degenerative horizontal tear of the medial meniscus be treated with surgery? Eklem Hastalik Cerrahisi 2018;29:63-4.

13. Roos EM, Roos HP, Lohmander LS, Ekdahl C, Beynnon BD. Knee Injury and Osteoarthritis Outcome Score (KOOS)-development of a self-administered outcome measure. J Orthop Sports Phys Ther 1998;28:88-96.

14. Paker N, Bugdayci D, Demircioglu UB, Sabirli F, Ozel S. Reliability and validity of the Turkish version of
Activities-specific Balance Confidence scale in symptomatic knee osteoarthritis. J Back Musculoskelet Rehabil 2017;30:461-6.

15. Lange AK, Fiatarone Singh MA, Smith RM, Foroughi N, Baker MK, Shnier R, et al. Degenerative meniscus tears and mobility impairment in women with knee osteoarthritis. Osteoarthritis Cartilage 2007;15:701-8.

16. Hodler J, Haghighi P, Pathria MN, Trudell D, Resnick D. Meniscal changes in the elderly: correlation of MR imaging and histologic findings. Radiology 1992;184:221-5.

17. Quinn SF, Brown TF. Meniscal tears diagnosed with MR imaging versus arthroscopy: how reliable a standard is arthroscopy? Radiology 1991;181:843-7.

18. Esmaili Jah AA, Keyhani S, Zarei R, Moghaddam AK. Accuracy of MRI in comparison with clinical and arthroscopic findings in ligamentous and meniscal injuries of the knee. Acta Orthop Belg 2005;71:189-96.

19. Ryzewicz M, Peterson B, Siparsky PN, Bartz RL. The diagnosis of meniscus tears: the role of MRI and clinical examination. Clin Orthop Relat Res 2007;455:123-33.

20. Gauffin H, Tagesson S, Meunier A, Magnusson H, Kvist J. Knee arthroscopic surgery is beneficial to middle-aged patients with meniscal symptoms: a prospective, randomised, single-blinded study. Osteoarthritis Cartilage 2014;22:1808-16.

21. Kise NJ, Risberg MA, Stensrud S, Ranstam J, Engebretsen L, Roos EM. Exercise therapy versus arthroscopic partial meniscectomy for degenerative meniscal tear in middle aged patients: randomised controlled trial with two year follow-up. Br J Sports Med 2016;50:1473-80.

22. van de Graaf VA, Wolterbeek N, Mutsaerts EL, Scholtes VA, Saris DB, de Gast A, et al. Arthroscopic Partial Meniscectomy or Conservative Treatment for Nonobstructive Meniscal Tears: A Systematic Review and Meta-analysis of Randomized Controlled Trials. Arthroscopy 2016;32:1855-65.

23. Atik OŞ. Do not treat the radiograph, treat the patient! Eklem Hastalik Cerrahisi 2015;26:125.

24. Atik OŞ. Do we surgeons perform surgery only? Eklem Hastalik Cerrahisi 2016;27:123-4. 